\title{
ENCOURAGEMENT OF WOMEN'S EMPLOYEE PERFORMANCE BASED ON A MODERN WORKING ENVIRONMENT AND WORK DISCIPLINE ON THE STORE CASHIER AND SALES PROMOTION GIRL
}

\author{
Mustikaningrum Hidayati \\ Faculty of Economics and Business,UNTAG Semarang \\ Email: mustika.mom@gmail.com \\ Honorata Ratnawati Dwi Putranti \\ Faculty of Economics and Business,UNTAG Semarang \\ Email: ratna.permai@gmail.com \\ Muchamad Ardiansyah \\ Faculty of Economics and Business,UNTAG Semarang \\ Email:sk8trsuck@gmail.com \\ Received: May 2019; Accepted: June 2019; Available online: July 2019
}

\begin{abstract}
Large cities are developing followed by the development of shops that are managed in a modern way. This condition opens opportunities for female employees to get jobs as sales promotion girls (SPG) and cashiers. SPG and cashiers as direct services to consumers, so that attention needs to be paid to the work environment and work discipline because these conditions can support services to consumers. This study aims to analyze the influence of the modern work environment and work discipline on performance, as well as driving indicators of the performance of female cashier and SPG employees in Semarang City. The population of this study is the SPG and the women's cashier of modern shops in Semarang City. This study uses technical snowball sampling and purposive random sampling with a total of 100 respondents. Distribution of questionnaires using google.docs (internet) on the link https://goo.gl/forms/ lxm7HfLSX4huuxwt1. The results of this study, there is a positive and significant relationship between the modern work environment and work discipline. The drivers of women's performance are explained by findings. Modern environments such as Wi$\mathrm{Fi}$ and pantry are things that can improve women's performance.
\end{abstract}

Keywords: Modern Work Environment, work discipline, SPG (Sales Promotion Girl) and Cashier

Abstrak
Kota-kota besar berkembang diikuti pula berkembangnya pertokoan yang di kelola secara modern.Kondisi ini membuka peluang bagi karyawan perempuan untuk mendapatkan lapangan pekerjaan sebagai sales promotion girl (SPG) dan kasir. SPG dan kasir sebagai pelayanan langsung kepada konsumen, sehingga perlu perhatian pada lingkungan kerja dan disiplin kerja, karena kondisi ini dapat menunjang pelayanan kepada konsumen.Penelitian ini bertujuan menganalisis tentang pengaruh lingkungan kerja modern dan disiplin kerja terhadap kinerja, serta indikator-indikator pendorong kinerja pegawai Kasir dan SPG perempuan di Kota semarang. Populasi penelitian ini adalah SPG dan kasir perempuan pertokoaan modern di Kota semarang, Penelitian ini menggunakan teknis snowball sampling dan purposive random sampling dengan jumlah 100 responden. Penyebaran kuesioner menggunakan google.docs (internet) pada link https://goo.gl/forms/ lxm7HfLSX4huuxwtl. Hasil penelitian ini, ada hubungan positif dan signifikan antara lingkungan kerja modern dan disiplin kerja.Faktor pendorong kinerja perempuan di jelaskan dengan temuan lingkungan modern seperti Wi-Fi dan pantry (dapur kecil) menjadi hal yang dapat meningkatkan kinerja perempuan.

Kata kunci: Lingkungan Kerja modern, disiplin kerja, SPG (Sales Promotion Girl) dan Kasir

How to Cite: Hidayati, M., Putranti, H. R. D., \& Ardiansyah, M. (2019). Encouragement of Women's Employee Performance Based on A Modern Working Environment and Work Discipline on The Store Cashier and Sales Promotion Girl. Media Ekonomi dan Manajemen, 34(2), 178-192. 


\section{INTRODUCTION}

Nowadays women and men have same opportunities to get into the workforce. Based on BPS data in2018 the Labor Force Participation Rate (LFPR) was increased (Badan Statistik, 2018). LFPR in February 2018 was recorded of 69.20 percent, increase of 0.18 percent points compared to a year ago. The increase in LFPR providesindicationof increasing economic potential in terms of workforce.Based on the gender LFPR in February 2018, male LFPR was 83.01 percent while female LFPR was only 55.44 percent. But it was compared to the condition a year ago, female LFPR increasedof 0.40 percent points while male LFPR decreased of 0.04 percent points. This condition describes employment opportunities for women experiencing an increase (Badan Statistik, 2018). Job opportunities according to the main sectors / business fields grew in 2016-2019, one of which was the provision of accommodation and the food and beverages in 2019 as many as 1,910,643 businesses field, major and retail trade about 26,849,893 business fields (Barembang, Kepnaker RI, 2018) .Retail trade employs women about 1,898,599 people and women workers in the food and beverage sector about 1,675,318 people (Statistics Agency, 2018). While for data from the National Labor Force Survey in August 2017, the active work force by gender, Semarang city in 2015, women were 359,338 people with the main employment status of workers/employees/as many as 228,160 people. This data shows that in this sector female workers quite dominate. Besides that it also shows, the dominance of female workers is quite a lot. The increasing number of female workers is caused by several factors such as, the better level of education of women, the opening of opportunities for women to work in the public sector, the appearance of industrialization, and the development of the trade sector.
Various opinions emerged about the rise of employment opportunities for women, including female workers considered more thorough. On the other hand female workers are considered not to be the main so that employerjust gives compensation not too high and are considered not to be the main in the world of work.It is considered to be something normal because of the Javanese philosophy that women as "koncowingking", it means women as housekeeper and limited activities (Nugraheni, 2012). But in reality women can work to help the family's economic and share their time for family, for this matter, of course, a well time management becomes a concern for women.

The development of Semarang has caused the wider growth of shops, malls, groceries, supermarkets that provide clothes, accessories, cosmetics and others. The developments in this sector also led to an increase of recruiting female employees as cashiers or Sales PromotionGirls. Cashier and Sales Promotion Girl are human resources that have an important role in a sales process. The important role is to convince buyers to decide on purchasing of a product and serve the payment process in buying and selling transaction. Achievethese target, causes SPG and cashierdirectly connect with prospective customers, which requires the SPG to be able to convince buyers so that transactions finally occur (Rizaldi, 2000). Likewise, the cashier at the store in serving costumer becomes the main determinant of consumensatisfaction. The results of a study conducted by Whireley in (Murdono, 2013) shows that most (almost 70\%) customers leave certain companies because of complaints about service quality (such as SPG), not because of the quality of their products. Consumen satisfaction is built by good products, good service by all parties, especially in parts that come in direct contact with consumen.

Entering the world of work will certainly face the work environment, the 
work environment is a situation that causes a sense of comfort and discomfort in doing work (Sarwani, 2016). The work environment is divided into three groups: the first, physically by providing services of food, health care, and bathroom. The second, working conditions consist of lighting, air conditioned room, noise level, room color selection, ventilation, tables and chairs (Casson, 2008). A balanced workplace with the organizational environment can optimize profits and increase the popularity of a pleasant workplace company so that it will ultimately attract qualified employees (Samson, 2015). Environment designers around the workplace will create conditions that can hinder, prevent, guide, support or enhance user behavior (Gutnik, Lilia, Tom Huang, 2007). The third, the problem of employees relationship with members of the organization, relationships with fellow employee or the relationship of employees with company leaders. The work environment also includes workplace safety which involves all the processes of labor protection against the possibility of danger occurrance. A good and pleasant work environment will result in employees working more happily so that organization goals can be achieved optimally.Instead, an environment that does not support workers adequately will have a bad impact so that it can reduce employee productivity. The work environment is dynamic and adaptive which means it is adapted to the times and adapted to the conditions that exist in the company working nowaday. Rational adjustments for changing that adjust to individual ability in accordance with their potential (Sedarmayanti, 2009).

Companies that provide jobs to women generally judge that women are more reliable in the areas of perseverance, discipline, thoroughness, and negotiation skills. Discipline as an HRM operative function will support the achievement of the organization, because with the existence of a good work discipline it will be able to achieve the determined goals effectively and efficiently (Hibau, 2018). When women undergo their careers, women faced multiple roles, namely, the role as wife, mother who nurses and cares for children (for those who are married) and for the unmarried to bear parents and siblings.Even though there is a change in status, the primary responsibility to manage home and family activities and rest for women who have multiple roles remains, even when she works full time outside the home (Fox, 2009). This busyness makes women often experience physical and psychological fatigue which results in attendance or absent in the workplace. In addition to this, safety factors must also be paid attention, because it becomes a big problem for women, especially if women finish working at night and have to go home by themselves, because the women who work as SPG and shop cashiers will go home after the shop closes and usually until evening. https://lifestyle.kompas.com/read/1/1/30/ $10425247 / 5$. In the article the problems faced by working women.

Having work discipline can have an impact on personal life of employeewho have an impact on the company. For this reason, the company needs to monitor every action and behavior carried out by employees while working. Work discipline will also build employee performance (Ernawati, 2018). Similar results of the research obtained by Rofi (2012) states that employee work discipline is the most dominant factor in improving employee performance. Work discipline is a factor that needs to be improved so that employee expectations can be achieved and get satisfaction in work. Satisfaction in working employees will help in achieving company's goals. The discipline of a person who develops in the work environment can be reflected in the desire and satisfaction that is fulfilled for something that causes a person to increase loyalty, obedience and compliance with the organization that leads to organizational achievement (Hibau, 2018) 
Research on employee performance has often been done, but there are some results that are inconsistent in the variables of the work environment and work discipline. The inconsistency of the results of research in this field is shown as research on work facilities that affect performance performed by Sari (2016). The results show that work facilities have a positive and significant effect on employee performance at the Office of the South Sanggata Sub-District of East Kutai Regency. The research results are the opposite of (Hayati, W.F., 2014). namely, the influence of work facilities on employee performance has a negative and no significant effect on performance. Subsequent research conducted by Parveen, Sohail, Naeem, Azhar and Khan (2012) to produce empirical office infrastructure has no significant effect on employee performance. The current results of the study focus more on the performance and work sectors that are mixed between male and female workers so that researchers are considered to be still biased in the results.

The problems that arise and the emergence of differences opinion about the work environment and work discipline raise questions, how the work environment and work discipline affects the SPG performance and how is the empirical description of the supporting indicators of employee performance of female cashiers and SPGs in Semarang City and the purpose of this study is to analyze the influence of work environment and work discipline on performance and supporting indicators of performance of female cashier and SPG performance employees in Semarang city.

\section{LITERATURE REVIEW Grand Theory}

The alteration in business world raises pressure in the competition, and the pressure. These pressures may related to environmental changes, such as increasing competition for resources. An organization with a high level of customization will be able to survive in a rapid environment, new millennium, highly developed and evolving technology. Resource-based theories looks the companies as a collection of resources and capabilities that owned by the company. The difference of resources and the ability of companies to competitor companies will provide a competitive advantage for the company. Or in the other words, the company can fundamentally be seen as a collection of resources and capabilities that set the foundation for competitive success (Barney, 1991; Barney, Wrightet \& Ketchen, 2001). The explanation of Wernerfelt (1984) on RBV (resource-based views) is, a fundamental competitive advantage that lies primarily in a group of tangible or intangible assets of the company. RBV provides an overview to manage the capabilities of company in providing a sustainable competitive advantage. The managed resources in such a way will produce an advantage that is difficult to emulate or make by competitors, and will eventually inhibit the competition (Mahoney \& Pandian, 1992). Knowledge, organisation culture, skill, and experience) is an valuable, unique, and inimitable resources. The value of intangible assets, and the ability can be customized by company because of the unique combination of the company's philosophy.In creating the adopted values supported by the organizational climate that provides the suport and the support that received by employees in work, as in Stringer's research (2002) stated the organizational climate indicators are: structures, responsibilities, awards, supports, and commitments.

\section{Employee Performance}

Optimal performance can be done by setting clear standards so that individuals who have behaviors will be responsible for their duties and responsibilities. So performance is the willingness of a person or group in completing 
responsibilities with the results as expected (Sinambela, 2017). The optimal achievement that can be done must be internal and external. Internal factors are driven by motivation. Motivation Deploy strength by taking action in fulfilling psychological needs or satisfaction in the work to achieve organizational goals. Performance is the implementation of the balance theory, which states that someone will show optimal performance when getting benefits (benefits) and there are stimuli (inducement) in his work fairly and it will (reasonable).

The balance theory shows that optimal performance will be achieved if there is a sense of justice felt by employees. Furthermore, external factors for outstanding employees are employees who should get stimulus from various parties that are involved in the form of motivation so that they are more active in carrying out activities and tasks that are their responsibility. One of the motivations for doing this activity is to create an adaptive work environment with the development of the future. The benefits of creating and maintaining a positive work environment are very large. Higher productivity, happier people, employee stability, business benefits, higher profits, greater security, and better health (Shrestha, 2007). Improving the work environment results in a decrease in the number of levels of errors, complaints, absences and hence improving performance.

\section{Modern work environment}

The work environment is very necessary to be considered because it is one of the important factors in determining the performance of employees. With a good working environment, employees can be encouraged to carry out everything well. They will feel happier and easier to concentrate on work so they have high performance. Whereas if the work environment is bad, it can also have a negative impact on the performance of the
employees.It is because they feel uncomfortable in working so that the performance becomes low (Casson, 2008).

The modern physical environment is distinguished by technology, computer, machine, public furniture and furniture that constantly affect the brain and health of employees. Health and happiness of employees will provide good motivation in achieving individual performance.A clean work environment can support the process of employee work activities, such as ventilation, room temperature regulation and garbage disposal, and the neatness of the room becomes a supporting to achieve good performance (Hamid, 2017). Supporting this, an organization must continue to develop itself in adapting to the modern work environment in accordance with the times so that it can create innovative and creative new thinking within the organization. Creative and innovative thinking is needed for the organizational development in the future (Sartika, 2015). The growth of the dynamics business world forces businesses to improve themselves in competition continously. The intensity of competition becomes a market measure for innovation, so that dynamic developments in competition are followed up with improvements in existing resources within the company, one of which is creating employee satisfaction with the support of environmental facilities work that is in line with the dynamics of time development (Riansyah \& Sy'roni, 2014). New thoughts that can be developed with the times will develop ways of working and how to provide services that aim to realize individual performance that is in accordance with organization goals.

H1 : Modern work environment influences employee performance.

\section{Work Discipline}

Work discipline in a company is important, because behavior in working in accordance with regulations and work procedures will help communication 
employees and company managers (Tohardi, 2002). The employees play an important role in determining employee perceptions of fairness in the context of discipline. Discipline is a major problem in the operation of an organization because it helps organization to achieve specific targeted goals. Research of work discipline (Anthony, 2017) shows that the work discipline of the private sector and states institutions is different, so that this condition will provide information for work discipline that is in accordance with the type of company to be able to provide significant benefits to the company and its employees.For companies, work discipline will guarantee the maintenance of rules and smoothness implementation of tasks so that optimal results can be achieved. Rules or standards of behavior can be defined as together hope a group. It includes what groups perceive as socially acceptable patterns of behavior for each individual in the group (Banda, 2004). For employee, the work discipline is expected to create a pleasant working atmosphere and by creating a pleasant working atmosphere will improve employee's anthusiasm. So that employee will consciously carry out their work and responsibilities within company (Sutrisno, 2009).

$\mathrm{H} 2$ :Work discipline influences employee performance.

\section{RESEARCH METHODS}

The research approach used in answering the problem statement is an explanatory research design, with the results of field data. The population of this study is female employees who work as cashiers, Sales Promotion Girls (SPG) in Semarang, whose numbers are unknown. This study uses technical snowball sampling and purposive random sampling with a total of 100 respondents consisting of female employee in Semarang. Snowball sampling is done to identify, select and take samples in a network or chain of relationships continuous while purposiveand snowball. Snowball is done by searching from the population that intended by researcher, the cashier and SPG in Semarang, then from the obtained sample were asked for the participation to chose their community as a sample again. Onward until the number of samples can be fulfilled.

Random sampling is the sample that is used according to the desired criteria by the author. Criterias that determined by the author are: women employee who work in the field of sales promotion girl and cashiers, work in Semarang, age above 20 years, have a minimum salary of Rp1,000,000/month up to Rp5,000,000/ month, minimum has worked for 3 months.

Distribution of questionnaires using google.docs (internet) on the link https://goo.gl/forms/lxm7HfLSX4huuxwt, making it easier for researcher to disseminate via social media and access via smart phone. Furthermore, open questions are processed using the atlas program version 8 . The results of the respondent description data can be seen as Table 1.

Most female workers are aged 20-25 years $(74 \%)$, has a meaning that employees are still in productive age and healthy, because the cashier and SPG require standing for a long time. Most recent education in Senior High School (65\%), shows the type of work in this field does not require formal education too high, but more prioritizing on appearance. The most research subjects is the SPG of 72 people or $72 \%$. It shows that in this field open opportunities and becomes job choices for women The highest monthly income is $\mathrm{Rp}$ 1,000,000-Rp 2,400,000 (52\%), which means that the received salary is in accordance with UMR in Semarang and marriage status $69 \%$ are unmarried, this indicates unmarried requirements will make it easier to reduce absenteeism. 
Table 1. The results of the respondent description data

\begin{tabular}{|c|c|c|c|}
\hline Category & Alternative Answer & Frequency $(\mathrm{F})$ & Percent (\%) \\
\hline \multirow[t]{4}{*}{ Ages } & $20-25$ years & 74 & $74 \%$ \\
\hline & $26-30$ years & 16 & $16 \%$ \\
\hline & $31-40$ years & 8 & $8 \%$ \\
\hline & Above 50 years & 2 & $2 \%$ \\
\hline \multirow[t]{6}{*}{ Education } & Junior High School & 4 & $4 \%$ \\
\hline & Senior High School & 65 & $65 \%$ \\
\hline & Diploma & 16 & $16 \%$ \\
\hline & Bachelor & 12 & $12 \%$ \\
\hline & Postgraduate & 2 & $2 \%$ \\
\hline & Others & 2 & $2 \%$ \\
\hline \multirow[t]{2}{*}{ Occupation } & Cashier & 28 & $28 \%$ \\
\hline & SPG & 72 & $72 \%$ \\
\hline \multirow[t]{4}{*}{ Monthly Income } & Rp $1.000 .000-2.400 .000$ & 51 & $51 \%$ \\
\hline & Rp 2.450.000-3.500.000 & 43 & $43 \%$ \\
\hline & Rp 3.600.000 - 4.000.000 & 3 & $3 \%$ \\
\hline & Above $\mathrm{Rp} 4.000 .000$ & 3 & $4 \%$ \\
\hline \multirow[t]{4}{*}{ Marriage Status } & Unmarried & 69 & $69 \%$ \\
\hline & Married & 19 & $19 \%$ \\
\hline & Widow & 12 & $12 \%$ \\
\hline & Unmarried & 69 & $69 \%$ \\
\hline
\end{tabular}

Source: Results of data processing, 2019

\section{RESULT AND DISCUSSION}

The results of the research data test instrument can be seen that all variables are valid and reliable. In the classic assumption test (multicollearity, heterocedasticity, and normality test) all variables meet the requirements, namely multicoleanerity test does not occur multicoleanerity, heterocedricity test that in the research model heterocedasticity does not occur, and the normality test is that the normal distribution is fulfilled.

Results of multiple regression work environment and work discipline towards employee performance can be seen in table 2. The work environment is 0.393 and the obtained positive value shows that a good work environment will be followed by employee performance. Work discipline 0.4734. The obtained positive value indicates an increase in the work environment will be followed by employee performance.
Results of the determination coefficient of work environment and work discipline on employee performance can be seen in Table 3. Adjusted R Square score of 0.587 can be interpreted that the work discipline and work environment can explain employee performance of $58.7 \%$ $(0.587 \times 100 \%)$. It means that it has a very strong influence because it is above $40 \%$, (Ghozali, 2016). The high and low work discipline is caused by the ups and downs of the work environment, and while for $41.3 \%$ (100\%-58.7\%). Employee performance is explained by variable of external the work discipline and work environment. These variables are for example: organization culture, organization climate, leadership in accordance with the case problems that occurred.

Based on the analysis results, it was found that the first hypothesis (H1) was accepted. The results of the t-test of the work environment for employee perfor- 
mance were 4, 954>0.340 and sig. 0,000 $<\alpha=0.05$ so accepting the hypothesis which state that the work environment has a positive and significant effect on the performance of female employee in the Semarang. It means that if the work environment provided by the company is good, then the employee's performance will be better.

This shows that the importance of the work environment to support employee performance. Because the better the work environment, the better the performance of female employee too. It is because of its positive and significant effect. It indicates that the work environment has been enjoyed by female employee in Semarang. They feel that they are given comfort while working in the company with the existing work environment, thus it will increase the employee performance who are in the company. The work environment is measured using indicators such as work atmosphere, relationship with co-workers, relationships between subordinate and leader and the availability of work facilities will make a positive and significant influence to improve the female employee performance, therefore the concern of company management to continue to improve a good work environment is a very important factor. In line with the research of Yulianingtyas (2008), Sanjaya and Indrawati (2014), and Setiawan and Dewi (2014), which stated that the work environment has a positive and significant effect on employee performance. The work environment affects performance positively and significantly. Improve effective and efficient performance, employees need work environment conditions that are supported by the leadership of the organization (Rokhilah \& Darmanto, 2014).

Based on the results of the analysis it was obtained that the second hypothesis (H2) was accepted. The results of the t-test of work discipline on employee performance were $5.960>0.389$ and sig. $0,000<\alpha=0.05$ so accepting the hypothesis that work discipline has a positive and significant effect on the performance of female employees in the city of Semarang. It means that if the discipline given by the company is good, then the employee's performance will be better. This shows that the importance of work discipline to support employee performance. Because the better the discipline employees have, the better the performance of female employees. It is because of its positive and significant influence. This indicates that work discipline has been widely applied by female employees in Semarang city. They feel the importance of improving performance through work discipline that every person must have. With the good discipline in each individual employee, the company can grow well. Work discipline is measured using indicators such as attendance, compliance with work regulations, adherence to work standards, high alertness, ethical work. With the existence of these indicators, companies can evaluate female employees so they can further improve the quality of the company. In line with the research of Pramana and Sudharma (2013), Koeswara and Budianto (2014), and Hetami (2008) which states that work discipline has a positive and significant effect on employee performance.

Indicator and category based on empirical finding can be seen in Table 4 . The empirical results about the current work environment experienced by SPG and female cashiers consist of physical facilities which consist of the following: Clean, cool place, neat, WI-FI, sufficient light and pantry. Information from each can be seen as Table 5 .

The modern work environment is supported by the discipline of work desired by female workers to improve performance. The desired work discipline consists of a timely, orderly presence in accordance with the rules, and clear rules. 
Information from each can be seen as Table 6.

Empirical results in the field for cashier employee performance, SPG consists of the accuracy of results and the ability to cooperate. Information from each can be seen as Table 7 .

In the developments that is occurred female employees need to be improved in performance. Things that can improve the performance of female employees at the operator level consist of bonuses, salaries, promotion, understanding, holidays. Information from each can be seen as Table 8.

From the results of the field described in each new finding indicator, a new model can emerge, namely that the performance of female employees at the operator level needs encouragement to be able to have good performance.Improved employee performance can be divided into qualitative motivator consisting of: promotion, understanding, vacation.
Quantitative motivator in the form of: bonuses, salary and job promotion, additional income because we complete a predetermined target. Giving bonuses is very pleasant for employees because the results achieved get an award. Promotional position is the desire of employees in their career path. Job promotion will have an influence on increasing income and income obtained Determination of salary in accordance with the City Minimum Wage of Semarang. Women want to be understood and need friends to tell stories and express their feelings so they need a good relationship between leaders and fellow friends. The development of the modern environment offers a balanced life balance between the workplace and the community, if it is not fulfilled the employees will be bored and stressed and disrupt performance. Stressful and saturated conditions are overcome by vacations at the facility by the company because of the heavy working hours of SPG and female cashiers. An explanation of the information can be seen in Figure 1.

Table 2. Results of Multiple Regression Work Environment and Work Discipline Towards Employee Performance

\begin{tabular}{|c|c|c|c|c|c|c|c|}
\hline \multirow[b]{4}{*}{ Model } & \multicolumn{5}{|c|}{ Coefficients $^{\mathrm{a}}$} & \multirow{2}{*}{\multicolumn{2}{|c|}{$\begin{array}{l}\text { Collinearity } \\
\text { Statistics }\end{array}$}} \\
\hline & \multicolumn{2}{|c|}{$\begin{array}{c}\text { Unstandardized } \\
\text { Coefficients }\end{array}$} & $\begin{array}{l}\text { Standardized } \\
\text { Coefficients }\end{array}$ & \multirow[b]{3}{*}{$\mathrm{T}$} & & & \\
\hline & & Std. & \multirow[b]{2}{*}{ Beta } & & \multicolumn{3}{|c|}{ Toleranc } \\
\hline & B & Error & & & Sig. & $\mathrm{e}$ & VIF \\
\hline (Constant) & ,891 & ,771 & & 1,156 & ,251 & & \\
\hline Work Environment (X1) & ,340 & ,069 & 393 & 4,954 & ,000 & 661 & 1,514 \\
\hline Work Discipline (X2) & ,389 & ,065 & ,473 & 5,960 &, 000 & ,661 & 1,514 \\
\hline
\end{tabular}

a. Dependent Variable: Employee Performance (Y)

Table 3. Results of the Determination Coefficient of Work Environment and Work Discipline on Employee Performance

\begin{tabular}{|c|c|c|c|c|}
\hline \multicolumn{5}{|c|}{ Model Summary ${ }^{b}$} \\
\hline Model & $\mathrm{R}$ & R Square & Adjusted R Square & Std. Error of the Estimate \\
\hline 1 &, $772^{\mathrm{a}}$ & 2,596 & ,587 & 2,116 \\
\hline
\end{tabular}


Table 4. Indicator and Category Based on Empirical Finding

\begin{tabular}{|c|c|c|c|c|}
\hline No & Variable & Old Indicator & Open Question Results & Category \\
\hline 1 & $\begin{array}{l}\text { Work } \\
\text { Environ- } \\
\text { ment }\left(\mathrm{X}_{1}\right)\end{array}$ & $\begin{array}{l}\text { 1. Work atmosphere } \\
\text { 2. Relationships with } \\
\text { coworkers } \\
\text { 3. Relations between } \\
\text { subordinates and leaders } \\
\text { 4. Availability of work } \\
\text { facilities }\end{array}$ & $\begin{array}{l}\text { 1. Clean } \\
\text { 2. A cool place } \\
\text { 3. Neat } \\
\text { 4. Wi-Fi } \\
\text { 5. Sufficient light }\end{array}$ & $\begin{array}{l}\text { Work Facility : } \\
\text { 1. Clean } \\
\text { 2. Cool Place } \\
\text { 3. Neat } \\
\text { 4. Wi-Fi } \\
\text { 5. Sufficient Lighting } \\
\text { 6. Pantry } \\
\text { Relationship : } \\
\text { 7. Relationship with co } \\
\text { workers } \\
\text { 8. Relationship with } \\
\text { leader }\end{array}$ \\
\hline 2 & $\begin{array}{l}\text { Works } \\
\text { Discipline } \\
\left(\mathrm{X}_{2}\right)\end{array}$ & $\begin{array}{l}\text { 1. Attendance } \\
\text { 2. Obedience to work rules } \\
\text { 3. Adherence to work standards } \\
\text { 4. High alertness level } \\
\text { 5. Work ethically }\end{array}$ & $\begin{array}{l}\text { 1. On time } \\
\text { 2. Firm } \\
\text { 3. Confusing } \\
\text { 4. OK } \\
\text { 5. Orderly } \\
\text { 6. Ordinary } \\
\text { 7. Strict } \\
\text { 8. Not good }\end{array}$ & $\begin{array}{l}\text { Attendance: } \\
\text { 1. On time } \\
\text { Obedience to } \\
\text { regulations } \\
\text { 2. Orderly } \\
\text { High alertness: } \\
\text { 3. Strict } \\
\text { 4. Confusing } \\
\end{array}$ \\
\hline 3 & $\begin{array}{l}\text { Employee } \\
\text { Performan- } \\
\text { ce }(\mathrm{Y})\end{array}$ & $\begin{array}{l}\text { 1. Work quantity } \\
\text { 2. Quality of work } \\
\text { 3. Time determination of } \\
\text { results } \\
\text { 4. Ability to work together }\end{array}$ & $\begin{array}{l}\text { 1. Bonus } \\
\text { 2. Salary } \\
\text { 3. Accuracy of results } \\
\text { 4. Ability to cooperate } \\
\text { 5. Awards } \\
\text { 6. Promotion of position } \\
\text { 7. Understanding } \\
\text { 8. Vacation }\end{array}$ & $\begin{array}{l}\text { Quantity } \\
\text { 1. Bonus } \\
\text { 2. Salary } \\
\text { 3. Accuracy of results } \\
\text { Quality } \\
\text { 4. Ability to cooperate } \\
\text { 5. Awards } \\
\text { 6. Promotion of position } \\
\text { 7. Understanding } \\
\text { 8. Vacation }\end{array}$ \\
\hline
\end{tabular}

Table 5. The Current Work Environment Experienced

\begin{tabular}{ll}
\hline Clean & $\begin{array}{l}\text { A clean place with no garbage, wanted by female workers, clean conditions make } \\
\text { workers feel comfortable to work. A clean place evokes a feeling of comfort. }\end{array}$ \\
\hline Cool place & $\begin{array}{l}\text { A cool place to install (AC) will make comfort in the room so that working to be } \\
\text { comfortable is not hot. Because the hot air becomes less comfortable }\end{array}$ \\
\hline Neat & $\begin{array}{l}\text { The items are arranged according to their place, objects that are related to work are } \\
\text { also well organized so that it will be easier to find the needed items. }\end{array}$ \\
\hline Wi-Fi & $\begin{array}{l}\text { At present the WI-FI requirement is a matter of convenience in working, WI-FI and } \\
\text { is used to access workers' android programs. As a tool for seeking entertainment, } \\
\text { social networking and increasing knowledge. An adaptive and modern environment } \\
\text { is a consideration of the comfort of the work environment for female employees. }\end{array}$ \\
\hline Light & Sufficient light, not dim will make employees move with pleasure and calm. \\
\hline Pantry & $\begin{array}{l}\text { Pantry is a small kitchen that is provided for employees to be able to move their } \\
\text { own food, make the desired drink. The condition of making women comfortable } \\
\text { because of their busy roles at home did not have time to prepare food from home. } \\
\text { Cooking and preparing your own food is fun because it suits your tastes and can } \\
\text { cook food more healthy and economical compared to snacks outside. }\end{array}$
\end{tabular}




\section{Table 6. The Modern Work Environment}

\begin{tabular}{ll}
\hline Attendance & The attendance of employees according to established working hours is as a \\
& matter in accordance with the labor law of the Republic of Indonesia. Law 13 of \\
& 2003. The working hours set when at the office are 8 hours of work, except for \\
Gajak drivers, there are no working hours because based on performance. \\
Whereas for cashiers and SPG they have working hours. Employees unable to \\
attend must provide information.
\end{tabular}

\section{Table 7. The Field for Cashier Employee Performance}

\begin{tabular}{ll}
\hline $\begin{array}{l}\text { Accuracy of } \\
\text { results }\end{array}$ & $\begin{array}{l}\text { The accuracy of the intended results is minimal error. For cashiers the right } \\
\text { financial calculation, for SPG goods and financial results as reported }\end{array}$ \\
\hline $\begin{array}{l}\text { Ability to work } \\
\text { together }\end{array}$ & $\begin{array}{l}\text { Working with friends is something that is needed by workers, because the work } \\
\text { performance of an employee is the result of good cooperation among all existing } \\
\text { employees. }\end{array}$ \\
\hline
\end{tabular}

Table 8. Things That Can Improve the Performance of Female Employees

\begin{tabular}{ll}
\hline Bonus & $\begin{array}{l}\text { Bonuses are defined as additional income because we complete a predetermined } \\
\text { target. The bonus is very pleasant for employees because the results achieved get } \\
\text { an award. }\end{array}$ \\
\hline Salary & $\begin{array}{l}\text { Salary is a fixed income each month given to employees. Salary in accordance } \\
\text { with the City Minimum Wage (CMW) that has been set for the high school level. } \\
\text { Additional determination will be in accordance with education, length of work } \\
\text { and work experience. }\end{array}$ \\
\hline Job Promotion & $\begin{array}{l}\text { Job promotion is the desire of employees in their career paths. Job promotion } \\
\text { will have an influence on increasing income and income earned. }\end{array}$ \\
\hline Understanding & $\begin{array}{l}\text { Understanding is a situation where a leader and friends can understand the } \\
\text { conditions and conditions currently being experienced by female workers, both } \\
\text { in matters of work or household work. }\end{array}$ \\
\hline Vacation & $\begin{array}{l}\text { A vacation or a picnic together is a pleasant situation. Make the physical } \\
\text { condition and mind rest and refresh to work again. }\end{array}$ \\
\hline
\end{tabular}




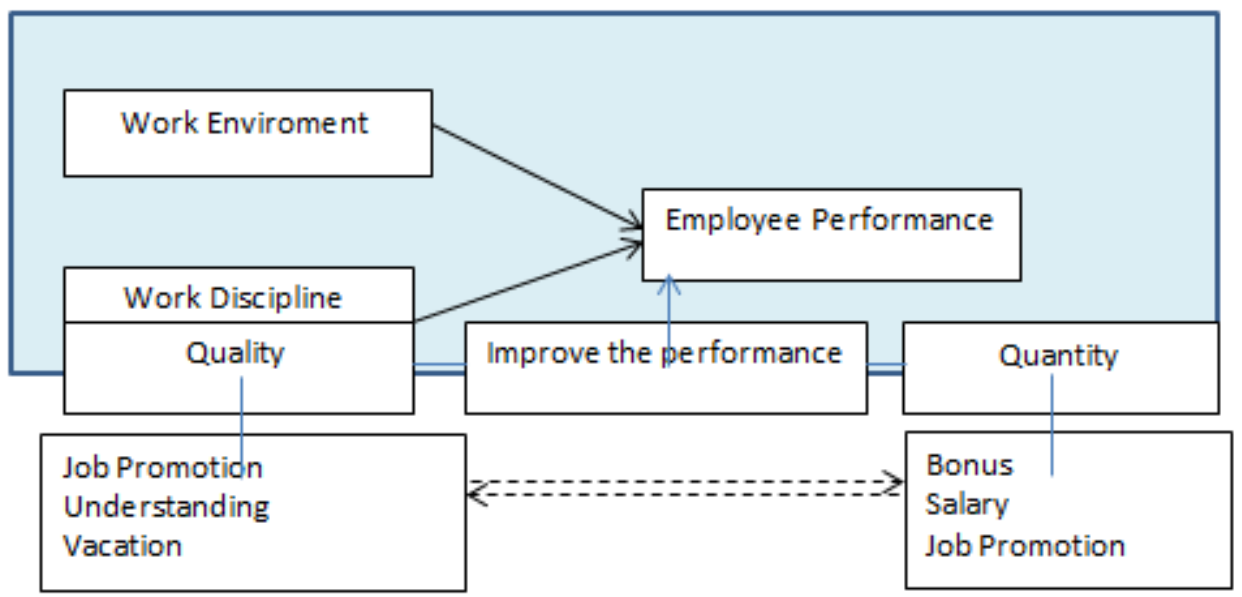

Figure 1. Performance Improvement Model

\section{CONCLUSION AND RECOMMEN- DATION}

Based on the results of the analysis and discussion in the previous chapter, it can be concluded that the work environment variable has a positive and significant effect on the performance of female employees in Semarang. Performance improvements will be made by the female employee. Variables of Work discipline has a positive and significant effect on the performance of female employees in theSemarang city. It means that if the work discipline is able to be applied to every individual female employee, then it can be ascertained that there is an increase in the performance of each female employee. Modern environments such as Wi-Fi and pantry parts of the modern environment are considered by companies to add to improve women's performance

\section{Suggestion}

It is necessary for additional facility that supports a comfortable work in order to improve the performance of female worker. These additions include tables, chairs, rooms, air conditioners. Further, evaluation of the achievement of the target of female workers because after all female workers are different from male workers in general, so that they cannot be equated with energy for these two workers. The existence of more in-depth research on female workers, because in the present era many women have entered the workforce and not a few of them have held the highest positions in the company.

\section{References}

Anthony, A. E. (2017). Effects Of Discipline Management On Employee Performance In An Organization: The Case Of County Education Office Human Resource Department, Turkana County. International Academic Journal of Human Resource and Business Administration, 2(3), 1-18.

Badan Statistik, 2018. (2018). Keadaan ketenagakerjaan Indonesia Februari 2018.

Barney, J. B. (1991). Firm Resources and Sustained Competitive Advantage. Journal of Management, 17(1), 99120.

Barney, J., Wright, M., \& Ketchen Jr., D.J. (2001). The Resource-Based View of the Firm: Ten Years After 1991. Journal of Management, 27(6), 625641. 
Bhat, V. M., Cole, J. W., Sorkin, J. D., Wozniak, M. A., Malarcher, A. M., Giles, W. H., . . . Kittner, S. J. (2008). Dose-response relationship between cigarette smoking and risk of ischemic stroke in young women. Stroke, 39(9), 2439-2443.

Casson, H. N. (2008). Pengambilan Keputusan Yang Efektif: Mengambil Keputusan Bijak Dan Bagaimana Menjalankannya. Yogyakarta: Hanggar Kreator.

Ernawati, F. Y. (2018). Membangun Kinerja Karyawan Melalui Kompensasi, Kompetensi Dan Disiplin Kerja Terhadap Kinerja Perawat RSI Sultan Agung Semarang. Fokus Ekonomi, 13(2), 331-341.

Firmanzah, A., Hamid, D., \& Djudi, M. (2017). Pengaruh Keselamatan Dan Kesehatan Kerja Terhadap Kinerja Karyawan (Studi Pada Karyawan PT. Pln (Persero) Area Kediri Distribusi Jawa Timur). Jurnal Administrasi Bisnis, 42(2), 1-9.

Ghozali, I. 2016. Aplikasi Analisis Multivariete Dengan Program IBM SPSS 23 (Edisi 8). Cetakan ke VIII. Semarang : Badan Penerbit Universitas Diponegoro.

Gutnik, L., Huang, T., Lin, J. B., \& Schmidt, T. (2007). New trends in product placement. Strategic Computing and Communication Technology, 1-22.

Hayati, W.F. (2014). Pengaruh Motivasi, Lingkungan Kerja Dan Fasilitas Terhadap Kinerja Karyawan Pt. Radio Suara Singgalang Mahimbau (Radio Sushi Fm) Padang. Jurnal Manajemen, UDINUS, 1-15.
Hetami, A. A.(2008). Pengaruh Motivasi, Kemampuan Dan Disiplin Terhadap Kinerja Karyawan Pada Sebuah Persero Asuransi. Jurnal Ekonomi dan Bisnis 6(2): 66-81.

Hibau, N. M. (2018). Disiplin Kerja pegawai berdasarkan kesetaraan gemder di kantor kecamatan Long Pahangai Kabupaten Mahakam Hulu. Ejournal Pemerintahan Integratif, 6(2), 263-272.

Https://lifestyle.kompas.com/read/2012/01/ 30/10425247/5.problem.yang.dihada pi.perempuan.bekerja. (2019). 5 Problem yang Dihadapi Perempuan Bekerja.

Koeswara, S. \& Budianto, H. (2011). Pengaruh Lingkungan Kerja dan Disiplin Kerja terhadap Kinerja karyawan. Jurnal PASTI, 4(2).

Mahoney, Joseph T; Pandian, J. Rajendran.(1992). The ResourceBased View Within the Conversation of Strategic Management. Strategic Management Journal, 13(5), $363-380$.

Murdono. (2013). Kualitas Pelayanan. Www.Sinarharapan.Com.

Nugraheni, W. (2012). Peran Dan Potensi Wanita Dalam Pemenuhan Kebutuhan Ekonomi Keluarga Nelayan. Journal of Educational Social Studies, 1(2), 104-111.

Parveen, S., Sohail, M. M., Naeem, F., Azhar, Z., \& Khan, S. H. (2012). Impact Of Office Facilities And Workplace Milieu On Employees' Performance: A Case Study Of Sargodha University. Asian Journal of Empirical Research, 2(4), 96-117. 
Pramana, K. \& Sudharma, I. N. (2013). Pengaruh kompensasi, lingkungan kerja fisik dan disiplin kerja terhadap kinerja karyawan. E-Jurnal Manajemen Universitas Udayana, 2(9), 1175-1188.

Riansyah, R., \& Sy'roni, D. A. W. (2014). Faktor-Faktor Yang Mempengaruhi Kreatifitas Dan Inovasi Serta Implikasinya Terhadap Kinerja Karyawan Pada Konsultan Perencanaan Dan Pengawasan Arsitektur Di Kota Serang, Provinsi Banten. Jurnal Ilmiah Magister Manajemen UNIKOM, 2(1), 1-17.

Rofi, A. (2012). Pengaruh disiplin kerja dan pengalaman kerja terhadap prestasi kerja karyawan pada departemen produksi PT Leo Agung Raya Semarang. Jurnal Ilmu Manajemen Dan Akuntansi Terapan, $3(1), 1-21$.

Rokhilah \& Darmanto, S. (2014). Pengaruh Kompetensi, Motivasi dan Lingkungan Kerja terhadap Kinerja Penyuluh Lapangan Program Keluarga Berencana (PLKB) di Kabupaten Pemalang. Jurnal Media Ekonomi dan Manajemen, 29(1), 6882.

Samson, G. N. (2015). Effect of Workplace Environment on the Performance of Commercial Banks Employees in Nakuru Town. International Journal of Managerial Studies and Research, 3(12), 76-89.

Sanjaya, E. \& Indrawati, D. (2014). Pengaruh kompetensi, kompensasi dan lingkungan kerja terhadap kinerja karyawan pada PT Pande Agung Segara Dewata. E-Jurnal Manajemen Universitas, 3(1), 205224.
Sari. (2016). Pengaruh Fasilitas, Lingkungan Kerja Dan Motivasi Terhadap Kinerja Pegawai Di Kantor Camat Sangatta Selatan Kabupaten Kutai Timur. EJournal Pemerintahan Integratif, 4(4), 505-519.

Sartika, D. (2015). Inovasi Organisasi Dan Kinerja Organisasi: Studi Kasus Pada Pusat Kajian Dan Pendidikan Dan Pelatihan Aparatur Lembaga Administrasi Negara. Jurnal Borneo Administrator 11(2), 129-151.

Sarwani. (2016). The effect of work discipline and work enviroment on the performance of employees. Sinergi: Jurnal Ilmiah Ilmu Manajemen, 6(2), 53-67.

Sedarmayanti, M. (2009). Sumber Daya Manusia dan Produktivitas Kerja. Bandung: Mandar Maju.

Setiawan, F. \& Dewi, K. (2014). Pengaruh kompen-sasi dan lingkungan kerja terhadap kinerja karyawan pada $\mathrm{CV}$ Berkat Anugrah. E-Jurnal Manajemen, 3(5), 1471-1490.

Sinambela, L. . P. (2017). Manajemen Sumber Daya Manusia Membangun Tim kerja yang solid untuk meningkatkan Kinerja. (R. D. Suryani, Ed.) (ke dua). Jakarta: Bumi Aksara.

Stringer. R. (2002). Leadership and Organizational Climate Upper Saddle River. New Jersey: Printice Hall.

Sutrisno, E. (2009). Manajemen Sumber Daya Manusia. Edisi pertama. Jakarta: Kencana Prenada Media Group.

Tohardi, A. (2002). Pemahaman Praktis Manajemen Sumber Daya Manusia. Bandung: Mandar Maju. 
Wernerfelt, B. (1984). A resource-based view of the firm. Strategic Management Journal, 5(2), 171180.

Yulianingtyas, R.W. (2008). Pengaruh Kepuasan Karyawan pada Gaya Kepemimpinan dan Lingkungan Kerja terhadap Kinerja Karyawan PT Yogyateks. Skripsi. Fakultas Ilmu Sosial dan Ekonomi. Universitas Negeri Yogyakarta. 